\title{
A new Silver Age?
}

\author{
The Spanish government has doubled research spending in four years. The next government must create \\ the legal structures to ensure that this money is wisely spent.
}

S pain's ruling Socialist Party came to power in 2004 vowing to reinvigorate its nation's turgid, bureaucracy-ridden research enterprise, and proceeded to make impressive progress towards that goal — not least by doubling the government's funding for science. But money is not everything. The next government, due to be elected on 9 March, will face the much harder challenge of modernizing the organization and management of Spanish science, so that the higher budgets can be spent more effectively.

Central to the reform effort is the Spanish National Research Council (CSIC), which has had a turbulent history as the government's leading research agency. The council was created in 1907 as the JAE, the Council for the Extension of Studies and Scientific Research, to promote science and foster links with European culture in general. The JAE operated a humming campus that hosted most of Spain's budding intellectuals at some stage in their creative lives, and helped to nurture Spain's 'Silver Age. This period in the early twentieth century saw Salvador Dalí paint his surrealist masterpieces, Luis Buñuel make avant-garde films, Federico García Lorca write sublime poetry, and Santiago Ramón y Cajal push the boundaries of neuroanatomy — work for which he won the 1906 Nobel prize.

The Silver Age was brought to an abrupt end in the mid-1930s by the Spanish Civil War. What followed, under the nearly four-decade dictatorship of Francisco Franco, can only be described as an intellectual dark age. Many of Spain's best scientists were driven into exile. Those that remained found themselves isolated. And the JAE, taken over by Franco and renamed the CSIC, had its intellectual ambitions drastically pared down.

The agency — and Spanish science in general — has struggled to recover ever since. For nearly 30 years after Franco's death in 1975, successive democratic governments introduced only the most hesitant reforms and budget increases. The CSIC grew to encompass 116 institutes and more than 150 research groups in universities. But it remained a stodgy bureaucracy in which buying a small item of equipment could take months and recruiting a scientist could take more than a year.

\section{Fresh impetus}

Hoping to improve matters, the current Socialist government came into office promising to double research funding; to turn the CSIC into an independent agency; and to create a separate, independent granting agency. The government fulfilled the first of these promises, more than doubling the research budget to over $€ 8$ billion (US $\$ 11.8$ billion). Spain's spending on research now exceeds $1.1 \%$ of its gross domestic product - still well below the European Union average of $1.8 \%$, but a major improvement over the level of $0.4 \%$ at the end of Franco's dictatorship. If it wins a second term, the socialist party plans to boost this figure to $2 \%$ by 2011 .

But the outgoing government has not done so well on the other two promises. It has laid the legal foundations for the much-needed granting agency, but the agency has yet to appear; the handful of competitive granting programmes that currently exist are offered by individual ministries, mostly earmarked for particular themes. And the promised liberation of the CSIC is still incomplete. The council was spun out of the science ministry to become an independent agency last December. But the heavy political representation on its executive board leaves scientists wondering how 'independent' it will actually be. The board is now drafting the by-laws of the CSIC agency, which will define exactly how it will operate.

Of particular concern to scien- "Spain's pockets of tists is whether these rules will scientific excellence reform Spain's inflexible system show that it is capable of of academic recruitment, which entering a new Silver Age." remains the biggest obstacle to efficiency. University professors and CSIC scientists alike are civil servants with total job security. As a result, hiring at any level is desperately slow, the hiring of foreigners is difficult, and it is almost impossible to offer anyone a competitive package of salary and research money.

\section{Cutting through the red tape}

This seemingly intractable problem has forced research administrators to devise ingenious work-arounds. The health ministry, for example, has created autonomous public-research institutes outside the standard system. One, the National Cancer Research Centre in Madrid, has built itself up into an internationally renowned centre just ten years after its founding. And although the CSIC's own institutes are still locked into conditions dictated by the science ministry, one of them, the National Centre for Biotechnology in Madrid, has managed to create its own 'pseudo-tenure-track' programme. It allows young scientists with their own research grants to move into space in its new start-up incubator building, which is not yet fully rented out.

The CSIC itself has done a good job over the past few years preparing itself for its new era as an agency. It has evaluated all of its institutes, closed three as a result, and merged many more to consolidate and focus research efforts. The real question is whether government officials, wary of what they see as losing control, will give it the freer rein it needs to realize its potential. Yes, the CSIC must operate under normal systems of accountability. But its new by-laws must allow it to offer proper career paths to its young scientists, and attractive packages to more senior scientists. If the bureaucrats don't ease up on their topdown control, the CSIC will be lost to mediocrity. The best scientists will go to the new autonomous institutes, which treat them better.

If the CSIC agency is allowed to develop appropriately, and an independent granting agency is created, then Spain will be well on its way to European norms. Spain's pockets of scientific excellence - reflected in its success in winning many of the first highly competitive European Research Council grants - show that the country is capable of entering a new Silver Age. If only its government will let it. 